\title{
PENGARUH PENERAPAN PENDIDIKAN MULTIKULTURAL TERHADAP SIKAP DAN TOLERANSI
}

\author{
Dewi Sartika ${ }^{1}$, Nasehudin ${ }^{2}$, Suniti $^{3}$ \\ Institut Agama Islam Negeri (IAIN) Syekh Nurjati Cirebon ${ }^{1,2,3}$ \\ dewisartika@syekhnurjati.co.id;cecenasehudin@syekhnurjati.co.id; \\ suniti@syekhnurjati.co.id
}

\begin{abstract}
ABSTRAK
Keberagaman etnis di Indonesia memunculkan sebuah kebutuhan akan pendidikan yang memperhatikan unsur kepedulian dan sensifitas terhadap masalah multikultur. Penelitian ini bertujuan untuk mengetahui pengaruh penerapan pendidikan multikutural terhadap sikap toleransi Siswa. Penelitian ini merupakan penelitian kuantitatif dengan jenis penelitian kuantitatif regresif, dan desain penelitian ini menggunakan penyebaran angket (questionneaire). Teknik pengumpulan data berupa observasi, wawancara, angket, dan dokumentasi. Teknik analisis data yaitu uji prosentase, uji normalitas, uji homogenitas, uji multikolinearitas, uji heteroskedastisitas, uji regresi linier berganda, uji koefisien derteminasi, uji hipotesis. Hasil penelitian menunjukan bahwa prosentase angket mengenai penerapan pendidikan multikultural adalah $84 \%$ dikategorikan sangat baik, mengenai sikap siswa didapatkan skor $80 \%$ dengan kategori baik dan mengenai toleransi siswa menyatakan bahwa kepribadian siswa menumbuhkan rasa saling bertoleransi pada kelas VIII SMP N 1 Ciwaringin Kabupaten Cirebon adalah 81\% dengan kategori sangat baik. Berdasarkan hasil penelitian bahwa nilai $\mathrm{F}$ hitung sebesar 39,712 > dari F tabel 3.29. Sehingga dapat disimpulkan bahwa variabel Pendidikan multikultural $(\mathrm{X})$ berpengaruh secara signifikan terhadap Sikap siswa $\left(\mathrm{Y}_{1}\right)$ dan Toleransi siswa $\left(\mathrm{Y}_{2}\right)$.
\end{abstract}

Kata Kunci: Pendidikan Multikultural, Sikap, Toleransi.

\section{ABSTRACT}

Ethnic diversity in Indonesia raises a need for education that pays attention to ignorance and sensitivity to multicultural problems. This study aims to study the effect of applying multicultural education to students' respect. This research is a quantitative research with regressive quantitative research type, and the design of this study uses a questionnaire (questionnaire). Data collection techniques consist of observation, interviews, questionnaires, and documentation. Data analysis techniques are percentage test, normality test, homogeneity test, multicollinearity test, heteroscedasticity test, multiple regression test, coefficient of dememination test, hypothesis test. The results showed the percentage of questionnaires regarding the application of multicultural education is $84 \%$ categorized very well, regarding the attitudes of students obtained a score of $80 \%$ with a good category and about student tolerance stating that student personalities foster a sense of mutual tolerance in class VIII SMP N 1 Ciwaringin Cirebon Regency is $81 \%$ with a very good category. Based on the results of the study that the calculated $F$ value of 39.712> from F table 3.29.

Jurnal Edueksos Vol. IX, No. 1, Juni 2020

The journal of social and economics education 
So it can be concluded that the variable multicultural Education $(X)$ significantly influences the attitude of students (Y1) and student tolerance (Y2).

Keywords : Multicultural education, Attitudes, Tolerance.

\section{A. PENDAHULUAN}

Pendidikan merupakan upaya untuk membantu peserta didik mengembangkan kemampuan yang dimilikinya. Selain itu, pendidikan merupakan upaya untuk membekali peserta didik agar memiliki kemampuan yang dapat bermanfaat bagi dirinya dalam kehidupan bermasyarakat, berbangsa dan bernegara. Pendidikan berbanding lurus dengan kemajuan suatu negara. Semakin baik pendidikan di suatu negara, maka akan semakin maju pula negara tersebut. Hal ini dikarenakan proses pendidikan yang baik akan dapat menghasilkan sumber daya manusia yang berkualitas, sehingga dapat membangun negaranya menjadi lebih baik. Keberagaman etnis di Indonesia memberi tantangan tersendiri dalam kehidupan multikultur sehingga sangat diperlukan kepedulian dan sensifitas terhadap masalah multikultur.Internalisasi multikulturalisme dapat diberikan mulai sejak pendidikan dasar karena merupakan penanamam konsep, nilai atau pemahaman awal kepada siswa.

Multikultural dan sikap toleransi sangatlah erat kaitannya, Na'im dan Syauqi menuliskan: "Ada beberapa aspek yang dapat dikembangkan dari konsep pendidikan multikultural yaitu, pertama ia berupaya menghargai dan merangkul segala bentuk perbedaan. Kedua, ia merupakan suatu upaya sistematis guna membangun pengertian, pemahaman dan kesadaran masyarakat mengenai realitas yang pluralis-multikultural. Ketiga, ia memberikan kesempatan kepada setiap masyarakat untuk berkembang dan tumbuh sesuai dengan latar belakang hidupnya. Keempat, ia membangun suatu konsep hidup egalitarianisme, kesetaraan, persamaan derajat dan hak hidup asasi”. (Yamin, 2011: 26-27).

Salah satu nilai karakter yang perlu ditanamkan di Indonesia ialah sikap toleransi. H.A.R Tilaar (2000: 180) mengemukakan bahwa wajah Indonesia yang Bhineka menuntut sikap toleran yang tinggi dari setiap anggota masyarakat. Sikap toleransi tersebut harus dapat diwujudkan oleh semua anggota dan lapisan masyarakat agar terbentuk suatu masyarakat yang kompak tetapi beragam sehingga 
kaya akan ide-ide baru. Sikap toleransi ini perlu dikembangkan dalam pendidikan. Meskipun upaya menanamkan sikap toleransi telah dilakukan melalui pendidikan di Indonesia, namun dalam kenyataannya belum semua sekolah memperhatikan penanaman sikap toleransi. Dalam mata pelajaran IPS kelas VIII terdapat materi yang membahas tentang "Multikulturalisme, Pluralisme, dan Demokrati-sme" tujuan dari pembelajaran tersebut siswa-siswi dapat menanamkan nilai-nilai sosial serta saling menghargai, toleransi, gotong-royong dan lain sebagainya.

Sekolah Menengah Pertama (SMP) Negeri 1 Ciwaringin adalah sekolah yang terletak antara daerah Kuningan dan Majalengka. Di sekolah ini ada dua suku bahasa yang sangat mendominasi di sekolah yakni siswa-siswi yang berbahasa Sunda dan Jawa. Permasalahan yang timbul adalah kondisi masih sulit saling menerima perbedaan yang ada. Peran pendidikan Multikultural belum mengarahkan dan membentuk sikap dan toleransi siswa yang menanamkan nilai-nilai sosial. Dengan demikian peran pendidikan Multikultural merupakan solusi untuk mengarahkan dan membangun sikap siswa yang saling menghargai, toleransi, gotong-royong, tanggung jawab dalam berinteraksi secara efektif dengan lingkungan sosial dan alam dalam jangkauan pergaulan serta keberadaannya, sehingga menghasilkan sikap toleransi siswa. Karena sikap dan toleransi merupakan sikap mengakui, menghargai, dan bertoleransi adanya keberagaman atau kemajemukan. Sedangkan pembelajaran pendidikan Multikultural ialah pembelajaran yang menekankan peran aktif siswa dalam membangun pemahaman dan memberikan makna terhadap informasi dan peristiwa yang dialami.

Berdasarkan uraian di atas, maka penulis tertarik melakukan penelitian dengan judul "Pengaruh Penerapan Pendidikan Multikultural Terhadap Sikap dan Toleransi Siswa di SMP Negeri 1 Ciwaringin Kabupaten Cirebon.”

\section{Pendidikan multikultural}

Pendidikan multikultural adalah strategi pendidikan yang diaplikasikan pada semua jenis mata pelajaran dengan cara menggunakan perbedaan-perbedaan kultural yang ada pada para siswa seperti perbedaan etnis, agama, bahasa, gender, kelas sosial, ras, kemampuan, dan umur agar proses belajar menjadi efektif dan mudah. Pendidikan multikultural sekaligus juga untuk melatih dan membangun karakter siswa agar mampu bersikap demokratis, humanis, dan pluralis dalam 
lingkungan mereka (Yaqin, M. Ainul, 2005: 25). Pendidikan multikultural sebagai suatu bidang studi dan disiplin baru yang bertujuan untuk menciptakan kesetaraan dalam pendidikan. Secara efektif, pendidikan multikultural berfungsi dalam kehidupan masyarakat multikultural yang demokratis (Wirasari, 2018: 77).

\section{Tujuan dan fungsi pendidikan multikultural}

Pendidikan multikultural mempunyai dua tujuan yaitu, tujuan awal dan tujuan akhir. Tujuan awal adalah tujuan sementara karena tujuan ini adalah perantara agar tujuan akhir dapat tercapai. Tujuan awal pendidikan multikultural adalah membangun wacana diantara guru, dosen, ahli pendidikan, pengambilan kebijakan dalam dunia pendidikan dan siswa (Yaqin, M. Ainul, 2005: 25). Artinya mereka mempunyai wacana yang baik tentang pendidikan multikultural maka mereka bisa mengajarkannya kepada peserta didik dan masyarakat lokal yang belum menguasai akan hal itu.

Tujuan akhir dalam pendidikn multikultural adalah peserta didik tidak hanya mampu memahami-memahami dan menguasai materi tentang pendidikan multikultural, namun mereka juga mampu menerapkan materi pembelajaran dalam karakter dan tingkah laku setiap hari (Yaqin, M. Ainul, 2005: 26).

The National Countil For Social Studies (Karwuyan, 2009:30) mengajukan sejumlah fungsi yang menunjukan pentignya keberadaan dari fungsi tersebut adalah: 1). Memberi konsep diri yang jelas, 2). Membantu memahami pengalaman kelompok etnis dan budaya ditinjau dari sejarahnya, 3). Membantu memahami bahwa konflik antar ideal dan realitas itu memang ada di setiap masyarakat, 4). Membantu mengembangkan pembuatan keputusan (decision making), partisipasi sosial dan keterampilan kewarganegaraan (citizenship skills), 5). Mengenal keberagaman dalam penggunaan bahasa.

Pendidikan multikultural memberi tekanan bahwa sekolah pada dasarnya berfungsi mendasari perubahan masyarakat dan meniadakan penindasan dan ketidak adilan. Fungsi pendidikan multikultural yang mendasar adalah mempengaruhi perubahan sosial. Jalan diatas dapat dirinci menjadi tiga butir perubahan, yaitu perubahan diri, perubahan sekolah dan persekolahan, perubahan masyaraka (Karwuryan, 2009: 30).

\section{Sikap Siswa}

Jurnal Edueksos Vol. IX, No. 1, Juni 2020

The journal of social and economics education 
Attitude (sikap) merupakan satu predisposisi atau kecenderungan yang relatif stabil dan berlangsung terus-menerus untuk bertingkah laku atau untuk mereaksi dengan satu cara tertentu terhadap pribadi lain. (Chaplin, J. P., 2000: 43).

W.A Gerungan (2010: 160) mengemukakan bahwa sikap (attitude) dapat diterjemahkan sebagai suatu sikap terhadap objek tertentu yang merupakan pandangan atau perasaan dan disertai dengan kecenderungan untuk bertindak sesuai dengan sikap objek tersebut. Lebih jelasnya, sikap merupakan kesediaan beraksi terhadap suatu hal.

Sejalan dengan hal tersebut, Meinarno dan Sarwono (2009: 82) mengemukakan bahwa sikap adalah suatu proses penilaian yang dilakukan oleh seseorang terhadap suatu objek. Menurutnya, sikap adalah konsep yang dibentuk oleh tiga komponen, yaitu kognitif, afektif, dan perilaku. Aspek kognitif yaitu semua pemikiran serta ide-ide yang berkaitan dengan objek sikap. Isi pemikiran tersebut meliputi hal-hal yang diketahuinya sekitar objek sikap. Aspek afektif meliputi perasaan atau emosi seseorang terhadap objek sikap. Emosi tersebut dapat berupa perasaan senang atau tidak senang terhadap objek, dan juga suka atau tidak suka terhadap objek sikap. Sedangkan aspek perilaku menunjukkan bagaimana perilaku atau kecenderungan berperilaku yang ada pada diri seseorang berkaitan dengan stimulus atau suatu objek yang dihadapinya.

Berdasarkan pengertian pengertian di atas dapat disimpulkan bahwa sikap merupakan kecenderungan seseorang untuk berperilaku terhadap suatu rangsangan atau objek sikap. Kecenderungan perilaku tersebut sesuai dengan konsep yang telah dibentuk oleh komponen kognitif, afektif, dan perilaku dalam diri seseorang. Kecenderungan berperilaku tersebut merupakan manifestasi dari perasaan atau emosi seseorang.

\section{Nilai-nilai Sikap yang Harus Diajarkan di Sekolah}

Seberapa jauh kita peduli tentang bersikap jujur, adil, dan pantas terhadap orang lain sudah jelas mempengaruhi apakah pengetahuan moral kita mengarah pada perilaku moral (Lickona, 2012: 90). Lickona (2012: 74-76) mengatakan bahwa terdapat nilai-nilai moral yang sebaiknya diajarkan di sekolah, yaitu;

1. Kejujuran 
Kejujuran adalah salah satu bentuk nilai. Dalam hubungannya dengan manusia, berarti adanya perilaku tidak menipu, berbuat curang, atau mencuri. Ini merupakan salah satu cara dalam menghormati orang lain.

2. Toleransi

Toleransi merupakan bentuk refleksi dari sikap hormat, sebuah sikap yang memiliki kesetaraan dan tujuan bagi mereka yang memiliki pemikiran, ras, dan keyakinan berbeda-beda. Toleransi adalah sesuatu yang membuat dunia setara dari berbagai bentuk perbedaan.

3. Kebijaksanaan

Kebijaksanaan merupakan nilai yang dapat menjadikan kita menghormati diri sendiri. Misalnya, ketika seseorang menjauhkan dirinya dari hal-hal yang dapat membahayakan diri baik secara fisik maupun moral.

\section{Disiplin Diri}

Disiplin diri membentuk seseorang untuk tidak mengikuti keinginan hati yang mengarah pada perendahan nilai diri atau perusakan diri. Tetapi untuk mengejar apa-apa yang baik bagi diri kita dan untuk mengejar keinginan positif dalam kadar yang sesuai. Disiplin diri dapat membentuk seseorang untuk tidak mudah puas terhadap apa yang telah diraih dengan cara mengembangkan kemampuan, bekerja dengan manajemen waktu yang bertujuan, dan menghasilkan sesuatu yang berarti bagi kehidupan. Semua itu bentuk dari sikap hormat.

5. Tolong-menolong

Sikap tolong-menolong dapat memberikan bimbingan untuk berbuat kebaikan dengan hati. Ini dapat membantu seseorang dalam menyelesaikan tanggung jawab terhadap etika yang berlaku secara luas.

6. Sikap Peduli Sesama

Sikap peduli sesama dapat diartikan "berkorban untuk". Sikap ini dapat membantu untuk tidak hanya mengetahui apa yang menjadi tanggung jawab kita, tetapi juga merasakannya.

7. Sikap Saling Bekerja Sama

Sikap saling bekerja sama mengenal bahwa "tidak ada yang mampu hidup sendiri di sebuah pulau (tempat kehidupan)" dan dunia yang semakin sering 
membutuhkan, kita harus bekerja secara bersama-sama dalam meraih tujuan yang pada dasarnya sama dengan upaya pertahanan diri.

8. Keberanian

Sikap berani akan membantu seseorang untuk menghormati diri sendiri agar dapat bertahan dalam berbagai tekanan. Sikap ini juga smembentuk manusia untuk menghormati hak-hak orang lain ketika kita mengalami sebuah tekanan.

\section{Demokrasi}

Demokrasi pada gilirannya merupakan cara yang diketahui terbaik dalam menjamin keamanan dan hak asasi masing-masing individu (untuk memiliki rasa hormat) dan juga mengangkat makna dari kesejahteraan umum (bersikap baik dan bertanggung jawab kepada semua orang).

\section{Toleransi Siswa}

Indonesia merupakan negara yang terdiri dari beraneka ragam suku, budaya, adat, ras, dan agama. Setiap daerah di Indonesia tentunya memiliki adat istiadat yang berbeda - beda. Hal itu juga tercantum dalam Qur'an Surat Al-Hujarat (49) ayat 13 yang berarti:

"Hai manusia, sesungguhnya Kami menciptakan kamu dari seorang laki-laki dan seorang perempuan dan menjadikan kamu berbangsabangsa dan bersuku-suku supaya kamu saling kenal-mengenal. Sesungguhnya orang yang paling mulia diantara kamu disisi Allah ialah orang yang paling taqwa diantara kamu. Sesungguhnya Allah Maha Mengetahui lagi Maha Mengenal.”

Ayat di atas menjelaskan bahwa Allah menciptakan manusia menjadi berbangsa-bangsa dan bersuku-suku untuk saling mengenal. Salah satu contohnya ialah negara Indonesia. Di Indonesia ini terdiri dari berbagai macam suku bangsa dan budaya. Hal tersebut diharapkan tidak menjadi jurang pemisah antara suku yang satu dengan yang lainnya, namun justru menjadi jembatan pemersatu bangsa Indonesia. Hal itu sesuai dengan semboyan bangsa Indonesia, yakni "Bhinneka Tunggal Ika" yang artinya adalah meskipun berbeda-beda namun tetap satu jua. Untuk menjaga keharmonisan kehidupan berbangsa dan bernegara, diperlukan sikap toleransi. Sikap toleransi ini diperlukan agar masyarakat yang berbeda suku 
maupun budaya dapat menerima dan menghargai perbedaan yang ada. Adapun sikap toleransi yaitu sikap saling menghargai dan menerima perbedaan orang lain.

Sejalan dengan hal tersebut, Mu'in (2011: 213) mengemukakan bahwa toleransi ialah suatu sikap menghormati orang lain yang berbeda dengan kita atau yang kadang seakan menentang kita dan memusuhi kita. Pendapat tersebut menjelaskan bahwa kita harus menjauhkan prasangka kita terhadap orang lain yang berbeda dengan kita. Meskipun seakan-akan orang lain memusuhi kita, namun kita harus tetap menghargai dan menghormatinya.

Selanjutnya, Michele Borba (2008: 232) mengemukakan bahwa toleransi ialah sikap saling menghargai tanpa membedakan suku, gender, penampilan, budaya, keyakinan, kemampuan, atau orientasi seksual. Orang yang toleran bisa menghargai orang lain meskipun berbeda pandangan dan keyakinan. Dalam konteks toleransi tersebut, orang tidak bisa mentolerir kekejaman, kefanatikan, dan rasialisme. Oleh karena itu, dengan adanya sikap toleransi ini orang-orang bisa menjadikan dunia menjadi tempat yang manusiawi dan damai.

Menurut Sumani (dalam Nugraha, 2012:23) pengertian toleransi adalah "Penanaman kebiasaan bersabar, tenggang rasa, dan menahan emosi serta keinginan. Toleransi diartikan sebagai suatu kualitas sikap membiarkan adanya pendapat, keyakinan, adat-istiadat, dan perilaku orang lain yang berbeda dengan dirinya". Sikap toleransi dalam penelitian ini adalah penegasan terhadap makna toleransi dalam kehidupan di sekolah sebagai salah satu bentuk dari suatu sistem sosial menjadi penting adanya, sebab jangan sampai terjadi penolakan terhadap nilai-nilai toleransi hanya dikarenakan siswa merasa cemas dan khawatir bahwa dengan toleransi itu menjadi bentuk perendahan diri, toleransi sesungguhnya berkembang dalam kerangka adanya keberagaman, utamanya adalah keberagaman SARA (Ramadhan, dkk: 2010).

Berdasarkan pengertian-pengertian tentang toleransi di atas, dapat disimpulkan bahwa toleransi ialah sikap menerima dan menghargai perbedaan-perbedaan yang ada serta tidak melakukan diskriminasi terhadap kaum minoritas. Perbedaan yang dimaksud meliputi perbedaan agama, ras, suku, bangsa, budaya, penampilan, kemampuan dan lain-lain. Tujuan dari sikap toleransi ini ialah membuat tatanan 
dunia yang penuh dengan kedamaian, sehingga kefanatikan dan kekejaman tidak dapat ditolerir.

\section{Penanaman Sikap Toleransi}

Untuk membentuk siswa menjadi insan yang bertoleransi, diperlukan suatu langkah agar tujuan tersebut dapat tercapai. Michele Borba (2008 : 234-257) menyatakan bahwa terdapat tiga langkah dalam menerapkan sikap toleransi kepada siswa, yaitu :

1. Mencontohkan dan menumbuhkan toleransi.

Dalam mencontohkan dan menumbuhkan toleransi, Hal yang dapat dilakukan oleh guru adalah:

a. Guru harus memerangi prasangka buruk kepada orang lain.

b. Guru harus bertekad untuk mendidik siswa yang toleran. Guru yang mempunyai tekad kuat akan memiliki peluang keberhasilan lebih besar, dikarenakan mereka merencanakan pola pendidikan yang diterapkan kepada siswa.

c. Jangan dengarkan kata-kata siswa yang bernada diskriminasi. Guru bisa menunjukkan reaksi ketidaksukaannya ketika melihat siswa berkomentar diskriminatif.

d. Beri kesan positif tentang semua suku. Biasakan mengajak siswa untuk membaca berita baik dari surat kabar atau televisi yang menggambarkan beragam suku bangsa.

e. Dorong siswa agar banyak terlibatdengan keragaman. Latihlah siswa agar bergaul dan berkomunikasi dengan masyarakat yang berbeda suku, agama, atau budaya.

f. Contohkan sikap toleransi dalam kehidupan sehari-hari. Cara terbaik dalam menanamkan sikap toleransi ialah dengan cara mencontohkan sikap-sikap tersebut dalam kehidupan sehari-hari.

2. Menumbuhkan apresiasi terhadap perbedaan

Dalam upaya menumbuhkan apresiasi siswa terhadap perbedaan, dapatdilakukan melalui beberapa cara berikut: 
a. Latih siswa untuk bisa menerima perbedaan sejak dini. Tugas guru di sini ialah menekankan kepada siswa bahwa perbedaan itu bukanlah masalah, justru dengan perbedaan dunia ini akan menjadi lebih berwarna.

b. Kenalkan siswaterhadap keragaman. Apabila siswa sering menemui keberagaman maka akan menambah wawasan bagi siswa bahwa banyak di luar sana yang berbeda dengan kita. Melalui hal ini, diharapkan siswa akan terbiasa dan belajar untuk menghargai keberagaman yang ada.

c. Beri jawaban tegas dan sederhana terhadap pertanyaan tentang perbedaan. Para siswa biasanya memiliki rasa ingin tahu yang besar. Oleh karena itu, ketika siswa bertanya mengenai perbedaan, maka hendaknya guru menjelaskan mengenai perbedaan tersebut menggunakan kalimat yang jelas dan mudah dipahami oleh siswa.

d. Bantu siswa melihat persamaan. Di samping perbedaan, bantu siswa untuk melihat persamaan dirinya dengan orang lain.

\section{B. METODE PENELITIAN}

Penelitian ini merupakan penelitian kuantitatif dengan jenis penelitian kuantitatif regresif, dan desain penelitian ini menggunakan penyebaran angket (questionneaire). Teknik dan Instrumen Pengumpulan Data yang digunakan yaitu observasi, wawancara, kuesioner atau angket, dan dokumentasi. Observasi digunakan untuk mengamati suasana yang akan diteliti, Wawancara digunakan untuk menggali data yang dilakukan dengan cara mendatangi langsung atau bertemu dengan responden atau sumber data dengan cara memberikan pertanyaan secara logis. Teknik pengumpulan data melalui wawancara ini juga sebagai pendahuluan untuk menemukan beberapa permasalahan yang terjadi dilapangan untuk dikaji serta ditelaah oleh peneliti. Dalam wawancara ini, dilakukan dengan guru yang mengajar pada mata pelajaran IPS. Teknik selanjutnya yaitu memberikan angket, Angket diberikan kepada siswa-siswi untuk mengumpulkan data mengenai permasalahan-permasalahan dalam proses pembelajaran. Pengambilan data melalui pemilihan siswa sebagai responden yang secara langsung karena dianggap bahwa siswa tahu keadaan di lapangan yang sebenarnya dan siswa terlibat dalam pelaksanaan penelitian dalam proses pembelajaran. Angket yang diberikan oleh peneliti kepada siswa-siswi berisikan pertanyaan- 
pertanyaan yang berkaitan dengan penerapan pendidikan multikultural, sikap siswa dan toleransi siswa. Pada angket penelitian ini, peneliti menggunakan instrumen penelitian dengan teknik Skala Likert dimana prinsip pokok Skala Likert adalah untuk menentukan lokasi kedudukan seseorang dalam mengukur sikap, pendapat, dan persepsi seseorang tentang fenomena tersebut dengan gradasi dari sangat positif sampai sangat negatif. Sedangkan teknik yang digunakan terakhit yaitu dokumentasi, yang dimaksud dokumentasi disini yaitu berupa datadata yang diperlukan antara lain tentang latar belakang SMP Negeri 1 Ciwaringin Kabupaten Cirebon yang meliputi sejarah, visi dan misi, tujuan, struktur organisasi dan lain-lain. Berdasarkan jenis penelitian dan teknik pengumpulan data penelitian ini, maka teknik analisis data yang digunakan adalah uji prosentase, uji normalitas, uji multikolinearitas, uji heteroskedastisitas, uji regresi linear berganda, uji koefisien derteminasi, uji hipotesis.

\section{HASIL DAN PEMBAHASAN}

\section{Penerapan Pendidikan Multikultural kelas VIII di SMP Negeri 1 Ciwaringin}

Berdasarkan hasil analisis data di lapangan dan pengolahan data variabel $\mathrm{X}$ (Penerapan Pendidikan Multikultural) yang telah dilakukan oleh peneliti, menyatakan bahwa penerapan pendidikan multikulturalpada kelas VIII di SMP N 1 Ciwaringin Kabupaten Cirebon termasuk ke dalam kategori sangat kuat. Dari hasil rekapitulasi skor angket, dapat dilihat bahwa angka rata-rata penerapan pendidikan multikulturalpada soal angket adalah 84\%. Angka ini berada diantara 81\%-100\% yang dikategorikan sangat kuat karena rata-rata respon siswa menjawab sangat setuju dan setuju untuk pernyataan angket yang bersifat positif begitupun sebaliknya.

Berdasarkan hasil wawancara dengan guru IPS bahwasannya Siswa dapat memahami bahwa pendidikan multikultural itu saling menghargai pendapat orang lain dan menerima perbedaan yang dimiliki oleh orang lain, Siswa juga dapat memahami adanya perbedaan toleransi, saling mengenal dan tidak membedabedakan. hal tersebut diharapkan tidak menjadi jurang pemisah antara suku yang satu dengan yang lainnya, namun menjadi jembatan persatuan.

Sikap siswa setelah mandapatkan pembelajaran pendidikan multikultural di kelas VIII SMP Negeri 1 Ciwaringin 
Berdasarkan pengolahan data variabel Y1 (Sikap siswa) yang telah dilakukan oleh peneliti, menyatakan bahwa kepribadian siswa pada kelas VIII SMP N 1 Ciwaringin Kabupaten Cirebon termasuk ke dalam kategori kuat.data yang diperoleh dari 35 responden dengan jumlah item angket sebanyak 15 maka skor ideal untuk angket tersebut adalah 15 item x 35 responden x 4 (skor tertinggi tiap item $)=2100$. Diketahui jumlah skor total sesuai dengan data penyebaran angket tentang sikap siswa setelah mandapatkan pembelajaran pendidikan multikultural adalah sebesar 1671. Dari hasil persentase angket di dapatkan skor 80\%, Skor tersebut tergolong pada kategori kuat yang berada di antara 80\% - 100\%, karena rata-rata respon siswa menjawab sangat setuju dan setuju dari angket yang bersifat positif begitupun sebaliknya.

\section{Toleransi siswa setelah mendapatkan pembelajaran multikultural di kelas VIII SMP Negeri 1 Ciwaringin}

Hasil pengolahan data variabel Y2 (Toleransi siswa) yang telah dilakukan oleh peneliti, menyatakan bahwa kepribadian siswa menumbuhkan rasa saling bertoleransi pada kelas VIII SMP N 1 Ciwaringi Kabupaten Cirebon termasuk ke dalam kategori sangat kuat. Dari hasil rekapitulasi skor angket, dapat dilihat bahwa angka rata-rata kepribadian siswa pada soal angket adalah $81 \%$. Angka ini berada diantara $81 \%-100 \%$ yang dikategorikan sangat baik, karena rata-rata respon siswa menjawab sangat sesuai dan sesuai untuk pernyataan positif dan sebaliknya.

\section{Pengaruh pendidikan multikultural terhadap sikap dan toleransi siswa kelas VIII SMP Negeri 1 Ciwaringin}

Untuk mengetahui apakah data berdistribusi normal atau tidak, dalam pengujiannya dilakukan dulu uji normalitas. Hasil dari angka diperoleh nilai signifikansi dari uji kolmogrov-smirnov sebesar 0,087 >0,05 artinya data tersebut berdistribusi normal.

Guna mengetahui apakah terdapat hubungan variabel yang sempurna diantara variabel independent atau semua variabel dari model regresi. Maka dilakukan uji multikolonieritas terhadap nilai angket dan didapat Nilai Tolerance variabel Sikap siswa (Y1) dan Toleransi siswa (Y2) yakni Siswa yaitu 0,804 dimana 0,804>0,1 dan nilai VIF memiliki nilai 1,243 dimana nilai tersebut $<10$. Dengan demikian 
dapat disimpulkan bahwa model regresi tersebut tidak terdapat multikolonieritas, artinya tidak adanya variabel bebas yang saling berkolerasi.

Guna mengetahui apakah dalam sebuah model regresi terjadi ketidak samaan varians dari residual suatu pengamatan ke pengamatan lain maka dilakukan uji heteroskedastisitas. Pada gambar hasil uji heteroskedastisitas dapat dilihat bahwa terdapat titik-titik yang menyebar dan tidak membentuk suatu pola tertentu seperti bergelombang atau membentuk sebuah garis, artinya bahwa model regresi ini tidak terjadi heteroskedastisitas melainkan hemoskedastisitas.

Guna mengetahui pengaruh penerapan pendidikan multikultural terhadap sikap dan toleransi siswa di kelas VIII SMPN 1 Ciwaringin Kabupaten Cirebon dilakukan uji regresi linier berganda. Dengan hasil persamaan regresi linier berganda diketahui nilai koefisien regresi variable sikap siswa (b1) sebesar 473 menujukkan bahwa ketika terjadi peningkatan variable sikap siswa sebesar 1 satuan maka penerapan pendidikan multikultural juga akan meningkat sebesar 473 satuan (dengan asumsi variable nilai lainnya tetap). Nilai koefisien regresi variable toleransi siswa (b2) bernilai positif yaitu 430. Hal ini berarti bahwa setiap peningkatan keaktifan siswa sebesar 1 satuan maka penerapan pendidikan multikulturaljuga akan meningkat sebesar 430 satuan(dengan asumsi variable nilai lainnya tetap). Nilai koefisien regresi variable sikap siswa (b1) dan toleransi siswa (b2) bernilai positif artinya terdapat hubungan positif antara sikap siswa dan toleransi siswa terhadap penerapan pendidikan multikultural, semakin tingginya sikap siswa dan toleransi siswa maka semakin meningkat penerapan pendidikan multikultural dan begitu pula sebaliknya.

Guna mengetahui bahwa R Square sebesar 0,713 menunjukkan bahwa tingkat pengaruh pendidikan multikultural terhadap sikap dan toleransi siswa. Hal ini juga ditunjukkan dengan besarnya presentase pengaruh pendidikan multikultural terhadap sikap dan toleransi siswa yaitu sebesar $71,3 \%$ dan sisanya sebesar $28,7 \%$ dipengaruhi faktor lain diluar daripenelitian.

Guna mengetahui apakah antara variabel tak bebas (Y) dan variabel bebas (X) mempunyai hubungan linier, peneliti melakukan uji linieritas dengan menggunakan software SPSS 24 dengan taraf signifikansi 0,05. Hasil uji F tersebut menunjukkan bahwa F hitung sebesar 39,712 dengan taraf signifikansi sebesar 0,000.ini 
kemudian dibandingkan dengan $\mathrm{F}$ tabel yang dihitung pada derajat bebas pembilang (df pembilang) sebesar 2 dan derajat bebas penyebut (df penyebut) sebesar 32 pada taraf 0,05 yang nilainya adalah 3.29. Tampak sangat jelas bahwa Fhitung $(39,712)$ lebih besar dari Ftabel (3.29). sehingga dapat disimpulkan bahwa variabel Pendidikan multikultural (X) berpengaruh secara signifikan terhadap Sikap siswa $\left(\mathrm{Y}_{1}\right)$ dan Toleransi siswa $\left(\mathrm{Y}_{2}\right)$.

Dari penjelasan di atas, peneliti dapat menyimpulkan bahwa terdapat pengaruh penerapan pendidikan multikultural terhadap sikap dan toleransi siswa kelas VIII di SMP Negeri 1 Ciwaringin Kabupaten Cirebon. Selain itu penerapan pendidikan multikultural memberikan dampak yang positif kepada siswa seperti sikap dan toleransi siswa dalam menghargai akan adanya perbedaan.

\section{KESIMPULAN}

Berdasarkan hasil analisis data dan pembahasan mengenai "Pengaruh Penerapan Pendidikan Multikultural Terhadap Sikap dan Toleransi Siswa di Kelas VIII SMP Negeri 1 Ciwaringin Kabupaten Cirebon. Maka dapat ditarik kesimpulan sebagai berikut:

1. Berdasarkan hasil analisis data di lapangan dan pengolahan data variabel $X$ (Penerapan Pendidikan Multikultural) yang telah dilakukan oleh peneliti menyatakan bahwa penerapan pendidikan multikultural pada kelas VIII di SMP N 1 Ciwaringin Kabupaten Cirebon termasuk kategori sangat baik. Dari hasil rekapitulasi skor angket dapat dilihat bahwa angka rata-rata penerapan pendidikan multikultural pada soal angket adalah $84 \%$ dengan kategori sangat baik.

2. Berdasarkan pengolahan data variabel Y1 (Sikap siswa) yang telah dilakukan oleh peneliti, di dapatkan skor $80 \%$ dengan kategori baik. Dengan demikian, sikap siswa setelah mandapatkan pembelajaran pendidikan multikultural di kelas VIII SMP Negeri 1 Ciwaringin adalah memiliki sikap jujur, peduli sesama, bekerja sama dan memiliki sikap demokrasi yang tinggi.

3. Berdasarkan pengolahan data variabel Y2 (Toleransi siswa) yang telah dilakukan oleh peneliti, menyatakan bahwa pendidikan multicultural dapat menumbuhkan toleransi pada siswa kelas VIII SMP N 1 Ciwaringi Kabupaten Cirebon, 
dibuktikan dari hasil rekapitulasi skor angket dengan angka rata-rata $81 \%$ dengan kategori sangat baik.

4. Berdasarkan hasil uji F antara variabel tak bebas Y1 (sikap siswa), Y2 (toleransi siswa) dan variabel bebas $\mathrm{X}$ (pendidikan multicultural) menunjukkan bahwa $\mathrm{F}$ hitung sebesar 39,712 dengan taraf signifikansi sebesar 0,000. Dari hasil penelitian bahwa nilai $F$ hitung sebesar 39,712 > dari F tabel 3.29. Sehingga dapat disimpulkan bahwa variabel Pendidikan multikultural (X) berpengaruh secara signifikan terhadap Sikap siswa $\left(\mathrm{Y}_{1}\right)$ dan Toleransi siswa $\left(\mathrm{Y}_{2}\right)$. Dengan demikian penerapan pendidikan multicultural memberi pengaruh signifikan dalam menumbuhkan sikap toleransi siswa.

\section{DAFTAR PUSTAKA}

Banks, James A dan Cherry A. McGee Banks. (2010). Multicultural Education: Issues and Perspectives. United States of America : John Wiley \& Sons, Inc.

Borba, Michele. (2008). Building Moral Intelegence. (Membangun Kecerdasan Moral: Tujuh Kebajikan Utama Agar Anak Bermoral Tinggi). Penerjemah: Lina Jusuf. Jakarta : PT Gramedia Pustaka Utama.

Chaplin, J. P. 2000. Kamus Lengkap Psikologi. Jakarta: Rajawali.

Grungan, W.A (2010). Psikologi sosial. Bandung: PT Refika Aditama.

Kawuryana, Sekar Purbarini.(2009). Handout Pendidikan Multikultural. Yogyakarta: Universitas Negeri Yogyakarta.

Lickona, Thomas. (2013). Educating for Catacter. (Pendidikan Karakter: Panduan Lengkap Mendidik Siswa Menjadi Pintar dan Baik). Penerjemah: Lita S. Bandung: Nusa Media.

Mu'in, Fatchul. (2011). Pendidikan Karakter. Yogyakarta: Ar-Ruzz Media.

Naim. 2008. Pendidikan Multikultural Konsep dan aplikasi. Yogyakarta: Arruz Media.

Nugraha, Heri. (2012). Implementasi Pendidikan Karakter Dalam Pendidikan Agama Islam di SMA Negeri 3 Semarang (tesis). Semarang: IAIN Walisongo.

Ramadhan, dkk. (2010). Pengaruh Pendidikan Multikultural dan Pendidikan Karakter terhadap Sikap Toleransi Siswa SMA Pancasila Sungai Kakap. Pontianak: Program Studi Magister Pendidikan Sosiologi. 
Tilaar, H.A.R. (2000). Pendidikan, Kebudayaan, dan Masyarakat Madani Indonesia. Bandung: PT Remaja Rosdakarya.

Tim Penulis Fakultas Psikologi UI. Eko A. Meinarno dan Sarlito W. Sarwono. (2009). Psikologi Sosial. Jakarta: Salemba Humanika.

Wirasari, dkk. 2018. Pengaruh Pelaksanaan Pendidikan Multikultural pada Mata Pelajaran Sejarah terhadap Sikap Pluralis Siswa Kelas IX SMA N 2 Pekalongan Tahun pelajaran 2017/2018. Indonesia Journal of History Education, 6 (1), 2018: p.76-88. Semarang: Jurusan Sejarah Universitas Negeri Semarang.

Yamin, Vivi Aulia, (2011). Meretas Pendidikan Toleransi. Malang: Madani Media.

Yaqin, Ainul. (2005) Pendidikan Multikultural. Yogyakarta: Pilar Media. 